\author{
Pawel Brezdeń, Joanna Drozdowska, \\ WALDEMAR SpalleK \\ Uniwersytet Wrocławski
}

\title{
Wybrane instytucje prorozwojowe związane z pomocą publiczną w aktywizacji polskiej gospodarki
}

\section{PoJĘCIE INSTYTUCJI PROROZWOJOWEJ I POMOCY PUBLICZNEJ}

$\mathrm{W}$ artykule podjęto problematykę wybranych instytucji prorozwojowych w Polsce, związanych z pomocą publiczną. Zadaniem instytucji prorozwojowych jest wspomaganie rozwoju przedsiębiorczości w regionie przez inicjowanie i realizowanie programów, tworzenie warunków do absorbowania osiagnięć nauki i techniki, ułatwianie i stymulowanie procesów aktywizacji gospodarczej oraz przyciaganie inwestorów. Do instytucji prorozwojowych należą między innymi agencje i fundacje rozwoju regionalnego i lokalnego, działające na rzecz rozwoju danego obszaru, współpracujące z samorządem lokalnym lub regionalnym. Ważną rolę w zakresie tworzenia potencjału naukowego regionu odgrywają instytuty i ośrodki badawczo-rozwojowe.

Szczególnym przypadkiem instytucji prorozwojowych są centra transferu technologii, parki technologiczne i inkubatory, które funkcjonują na styku biznesu i sfery badawczo-rozwojowej, a także aktywnie współpracują z samorządem i wspierają rozwój przedsiębiorczości (często związanej z branżami innowacyjnymi). Właściwe funkcjonowanie wspomnianych instytucji i realizowanie przez nie wyżej określonych celów gospodarczych wymaga odpowiednich środków finansowych. Ich uzyskiwanie na drodze komercyjnej nie zawsze jest wystarczające. Wówczas niezbędne jest wspieranie ich działalności ze środków publicznych.

Pomoc publiczna jest wsparciem (przeważnie finansowym) dla pojedynczego podmiotu lub określonej kategorii podmiotów udzielanym przez instytucje zarówno państwowe, jak i samorządowe. Może ona przybierać różne formy, co często prowadzi do zarzutu naruszania zasad wolnej konkurencji i tworzenia nierównowagi na rynku. Pomoc publiczna stanowi ważny instrument realizacji polityki gospodarczej, szczególnie regionalnej i strukturalnej. Jej działania są zogniskowane na poprawie ekonomicznej efektywności gospodarki, zwiększenia jej konkurencyjności, przezwyciężania barier i ograniczeń rozwojowych, a także unowocześniania gospodarki przez rozwój dziedzin utożsamianych z postępem technologicznym i organizacyjnym. Dlatego zadaniem pomocy publicznej jest podejmowanie działań zmierzających do usuwania przeszkód uniemożliwiających pełne funkcjonowanie mechanizmu 
rynkowego oraz tworzenie mechanizmów alternatywnych w sytuacjach, gdy prawa rynku okazują się niewystarczające do rozwiązywania określonych problemów gospodarczych na rynkach lokalnych i regionalnych.

Aby wsparcie finansowe zostało uznane za pomoc publiczną, musi spełniać określone warunki. Pomocą publiczną określamy bowiem wszelkie wydatkowanie środków publicznych lub uszczuplanie danin publicznych w celu wspierania przedsiębiorstw lub produkcji określonych towarów, stanowiące korzyść ekonomiczną dla beneficjanta. Traktat o Wspólnocie Europejskiej nie zawiera precyzyjnej definicji pomocy publicznej, a jedynie przesłanki, które zostały ujęte w art. 87 ust. 1 (Matusiak, Bąkowski 2008).

Występowanie pomocy publicznej uwarunkowane jest następującymi przesłankami, które muszą być spełnione łącznie (Pomoc publiczna... 2009):

1) pomoc jest udzielana przez organy administracyjne (rządowe, samorządowe) lub wszelkie inne podmioty kontrolowane przez państwo lub zarządzające środkami publicznymi;

2) wsparcie skutkuje przysporzeniem korzyści finansowej na rzecz określonego podmiotu, na warunkach korzystniejszych niż rynkowe - tzw. korzyść ekonomiczna;

3) uprzywilejowanie określonych przedsiębiorstw lub sektorów, dyskrecjonalna władza organu udzielającego, ograniczenie zasięgu terytorialnego - tzw. selektywność;

4) wsparcie zakłóca konkurencję lub grozi zakłóceniem konkurencji oraz wpływa na wymianę handlową między państwami członkowskimi.

Wskazane wsparcie finansowe nie może w sposób istotny naruszać konkurencji przez uprzywilejowanie niektórych przedsiębiorców, produkcji towarów lub też określonych usług. Niestety, takie ryzyko zawsze istnieje. Wspomagane przedsiębiorstwa bądź produkty zyskują bowiem lepszą pozycję wyjściową na rynku, zaburzając wymianę handlową w obrębie gospodarki krajowej oraz obszaru gospodarczego Unii Europejskiej (Ustawa o postępowaniu... 2004).

Pomoc publiczna może przybierać różnorodne formy, np. dotacji; zwolnienia, obniżenia, odliczenia podatku; refundacji, oddania do użytkowania mienia, wniesienia kapitału itd. ${ }^{1}$. Może być kierowana do regionów, sektorów gospodarki lub kategorii przedsiębiorstw. Dlatego są wyodrębniane jej następujące kategorie (Kierunki udzielania pomocy... 2007):

- pomoc regionalna, przeznaczona na wyrównywanie poziomu gospodarczego regionów państw członkowskich. Udzielana jest na podstawie art. 87 ust. 3 lit. a i c TWE. Pomoc ta jest udzielana przedsiębiorstwom na nowe inwestycje oraz na tworzenie miejsc pracy związanych z tą inwestycją;

- pomoc sektorowa, udzielana szczególnie tzw. sektorom „wrażliwym” gospodarki, z nadmiarem zdolności produkcyjnej (górnictwo węgla, hutnictwo żelaza i stali, motoryzacja, produkcja włókien syntetycznych, budownictwo okrętowe, żegluga morska), w celu ich restrukturyzacji lub utrzymania sektora przez ograniczenie przyrostu produkcji. Pomoc może mieć w tym przypadku dwojaki charakter: ochronny - ukierunkowany na restrukturyzację lub utrzymanie sektora przez ograniczenie przyrostu produkcji, oraz stymulujący wzrost produkcji - w wypadku, gdy sektor nie jest w stanie poradzić sobie przy użyciu własnych środków z rosnącym popytem na produkty;

\footnotetext{
${ }^{1}$ Szczegółowa typologia form pomocy publicznej jest zawarta w Rozporzqdzeniu Rady Ministrów w sprawie sprawozdań o udzielonej pomocy publicznej oraz sprawozdań o zaległych należnościach przedsiębiorców z tytulu świadczeń na rzecz sektora finansów publicznych z dn. 12 lipca 2007, Dz. U. 2007, nr 133, poz. 923.
} 
- pomoc horyzontalna, skierowana do przedsiębiorstw bez względu na sektor gospodarki oraz region i udzielana w szczególności na badania i rozwój $(B+R)$ oraz innowacje, a także na ochronę środowiska, szkolenia, głownie dla małych i średnich przedsiębiorstw.

Na podstawie Sektorowego Programu Operacyjnego Wzrost Konkurencyjności Przedsiębiorstw oraz Ustawy o zmianie ustawy o finansowym wspieraniu inwestycji oraz warunkach dopuszczalności i nadzorowaniu pomocy publicznej dla przedsiębiorców $w^{2}$ obszarami pomocy publicznej są: specjalna strefa ekonomiczna, park przemysłowy, park technologiczny, inkubator technologiczny, inkubator przedsiębiorczości, park naukowo-technologiczny, klaster (Specjalne strefy ekonomiczne... 2008). Wymienione wyżej instytucje korzystają z bardzo różnorodnych form pomocy publicznej, przyciagając inwestorów i tworząc nowe miejsca pracy.

Specjalna strefa ekonomiczna (SSE) - to wyodrębniona administracyjnie cześć terytorium Polski, przeznaczona do prowadzenia działalności gospodarczej na preferencyjnych warunkach. Korzystanie ze zwolnienia podatkowego z tytułu działalności na terenie specjalnej strefy ekonomicznej jest jedną z najważniejszych możliwości uzyskania pomocy publicznej przez podmioty prywatne.

Park przemysłowy - to zespół wyodrębnionych nieruchomości wraz z infrastrukturą pozostała po restrukturyzowanych lub likwidowanych przedsiębiorstwach oraz inne dołączone do nich nieruchomości, utworzony przy udziale władz samorządowych w celu zapewnienia możliwości prowadzenia działalności gospodarczej, w szczególności dla przedsiębiorstw z sektora MSP, na preferencyjnych warunkach.

Park technologiczny - to utworzony przy udziale władz samorządowych wyodrębniony zespół naukowo-przemysłowy, oferujący przedsiębiorstwom nowoczesne technologie i usługi w zakresie doradztwa w tworzeniu i rozwoju przedsiębiorstw, transferu technologii i komercjalizacji wyników badań naukowych, a także udostępniający tym przedsiębiorcom nieruchomości wraz z infrastrukturą.

Park naukowo-technologiczny - jest tworzony w celu promowania lokalnej i regionalnej gospodarki poprzez wspieranie przedsiębiorczości, innowacji i transferu technologii. Pomaga tworzyć nowe przedsiębiorstwa i wspierać rozwój istniejących, szczególnie z sektora MSP.

Inkubator przedsiębiorczości - instytucja, której zadaniem jest szeroko rozumiana pomoc dla firm rozpoczynających działalność. Jej zadaniem jest wprowadzenie na rynek i ochrona (inkubacja) nowo powstających przedsiębiorstw. Efektem działalności inkubatora jest rozwój małej i średniej przedsiębiorczości, powstawanie nowych miejsc pracy, a przez to poprawa sytuacji gospodarczej regionu i jego mieszkańców.

Inkubator technologiczny - to inkubator przedsiębiorczości wyspecjalizowany we wspieraniu nowych form działalności opartych na zaawansowanych technologiach. Może to być inkubator przedsiębiorczości akademickiej oraz inkubator tworzony w parkach technologicznych.

Klaster - to przestrzennie skoncentrowana grupa firm, związanych z jedną branżą gospodarczą (jądro), i branż wspierających. Podstawą klastra jest jednoczesna kooperacja i konkurencja zgrupowanych podmiotów, wyspecjalizowanie w konkretnej dziedzinie i wykorzystanie wspólnych technologii i umiejętności. Zadaniem władz publicznych (wszystkich poziomów) jest pomoc w nawiązywaniu kontaktów i współpracy między nimi. Klaster ma

2 Dz. U. 2003, nr 159, poz. 1537, z późn. zm. 
szanse powstać tam, gdzie jest duży potencjał w określonym obszarze, a między firmami i instytucjami, które w nim działają, tworzą się powiązania kooperacyjne, handlowe, badawcze, marketingowe, regulacyjne i edukacyjne.

W ostatnich latach preferowana dotąd przez UE pomoc sektorowa i regionalna utraciły znaczenie na rzecz pomocy horyzontalnej. W 2007 r. ich udział w ogólnej wielkości pomocy publicznej kształtował się odpowiednio na poziomie $9,2 \%$ oraz $24,9 \%$, przy $65,5 \%$ udziale pomocy horyzontalnej (ryc. 1). W wypadku pomocy horyzontalnej zwraca jednak uwage nadal niski udział pomocy kierowanej na prace badawczo-rozwojowe $(5,3 \%) \mathrm{w}$ analizowanym roku (ryc. 2). Dlatego następuje stopniowe marginalizowanie znaczenia specjalnych stref ekonomicznych z jednoczesnym przyznawaniem priorytetowego miejsca parkom i inkubatorom. SSE w większości realizują zadania związane z restrukturyzacją gospodarki i złagodzeniem skutków społecznych transformacji gospodarczej, a więc korzystają ze środków pomocy regionalnej i sektorowej.

Działalność parków i inkubatorów w znacznej mierze skupiona jest na unowocześnianiu gospodarki i stąd jest ściślej związana z horyzontalnymi celami pomocy publicznej. Podmioty w klastrach natomiast korzystają głównie z pomocy de minimis, a więc o niewielkiej wartości i nienaruszającej konkurencji.

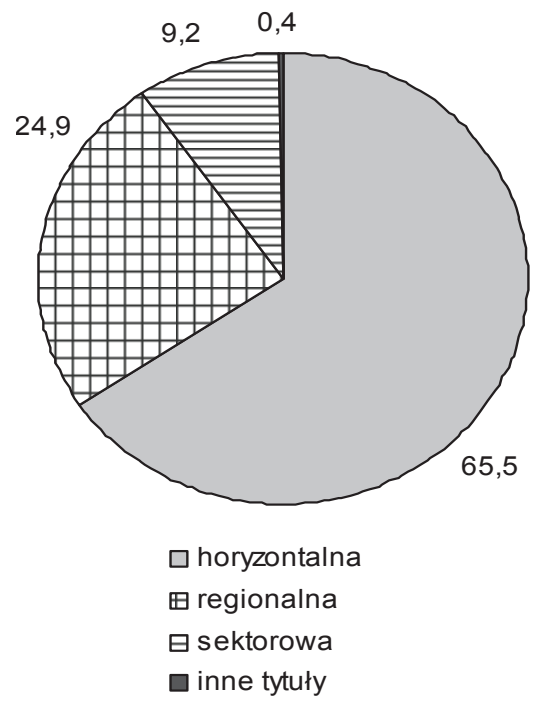

Ryc. 1. Struktura pomocy publicznej w $2007 \mathrm{r}$.

Źródło: Opracowanie własne na podstawie Raport o pomocy... 2008

Z uwagi na rosnące znaczenie instytucji parkowych i inkubatorów w gospodarce przedmiotem analizy w niniejszym opracowaniu będą instytucje prorozwojowe, związane z kategorią pomocy horyzontalnej: parki (przemysłowe, naukowe i technologiczne) oraz inkubatory (przedsiębiorczości i technologiczne). Pomoc horyzontalna umożliwia rozwój sfer o najwyższej efektywności ekonomicznej, będących nośnikami postępu cywilizacyjnego i tworzących efekty mnożnikowe. W analizie nie uwzględniono klastrów, dlatego że na 
obszarze Polski mają one postać inicjatyw klastrowych i nie ma możliwości określenia ich wpływu na gospodarkę.

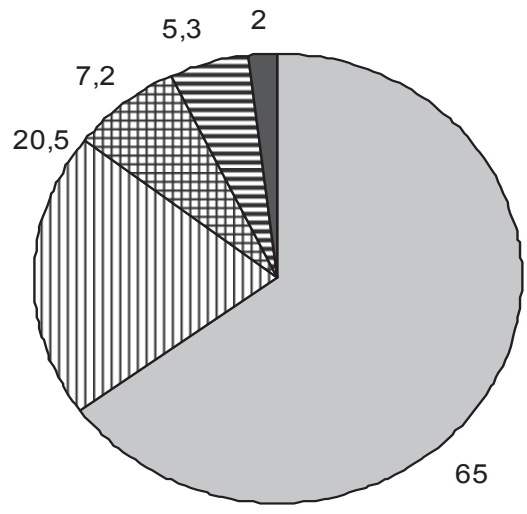

$$
\begin{aligned}
& \square \text { pomoc na zatrudnienie } \\
& \text { ஐ rozwój sektora MSP } \\
& \text { 田 szkolenia ogólne } \\
& \text { 日 prace B+R } \\
& \square \text { inne }
\end{aligned}
$$

Ryc. 2. Struktura pomocy horyzontalnej w Polsce w 2007 r.

Źródło: Opracowanie własne na podstawie Raport o pomocy... 2008

Badanie wspomnianych instytucji prorozwojowych, zarówno w ujęciu przestrzennym, jak i czasowym, jest utrudnione ze względu na brak wiarygodnych danych statystycznych. W opracowaniu wykorzystano informacje zawarte w raportach organizacji pozarządowych (Stowarzyszenia Organizatorów Ośrodków Innowacji i Przedsiębiorczości, Urzędu Ochrony Konkurencji i Konsumentów, Polskiej Agencji Rozwoju Przedsiębiorczości), zajmujących się tematyką instytucji parkowych i inkubatorów. Cennym źródłem danych okazały się również strony internetowe analizowanych instytucji, korzystających z pomocy publicznej. W związku z brakiem spójnych i wiarygodnych danych, charakteryzujących pełną zbiorowość instytucji prorozwojowych w Polsce, analizie poddano te instytucje, dla których była ona możliwa i w zakresie wybranych aspektów ich działalności. W opracowaniu szerzej została omówiona grupa 15 parków technologicznych, 11 inkubatorów technologicznych i 36 inkubatorów przedsiębiorczości.

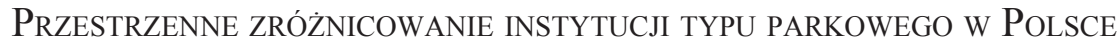

Pierwsze instytucje typu parkowego zaczęły powstawać w Polsce w drugiej połowie lat dziewięćdziesiątych XX wieku. Zapoczątkowany w 1989 r. okres transformacji ustrojowej zrodził potrzebę restrukturyzowania i rewitalizowania obszarów przemysłowych oraz zwiększenia innowacyjności krajowej gospodarki. Dlatego w Polsce, na wzór kra- 
jów Europy Zachodniej i Stanów Zjednoczonych, zaczęto powoływać instytucje parkowe o znaczeniu przemysłowym: parki przemysłowe, przemysłowo-technologiczne oraz w większym stopniu ukierunkowane na kreowanie i wdrażanie innowacji - parki technologiczne, naukowo-technologiczne i naukowe. Pierwszym organizmem gospodarczym, noszącym znamiona parku, był Warszawski Park Przemysłowy utworzony w 1993 r., natomiast pierwszym parkiem technologicznym, łączącym sferę nauki z biznesem, był Poznański Park Naukowo-Technologiczny, który swoją działalność rozpoczął w 1995 r. Kolejne dwa parki powstały w 1998 r. we Wrocławiu i Koszalinie.

Znaczne przyśpieszenie tworzenia tego typu instytucji prorozwojowych nastapiło po 2001 r. W ciągu trzech lat powołano aż dwanaście różnych parków, w tym siedem przemysłowych. Akcesja Polski do Unii Europejskiej nasiliła jeszcze bardziej zjawisko masowego tworzenia tego rodzaju instrumentów pomocy publicznej. Pomiędzy 2004 a 2006 r. utworzono dwadzieścia jeden jednostek typu parkowego. Przyczyną tego znacznego przyrostu było zwiększenie dostępności do środków finansowych z programów pomocowych Unii Europejskiej. Również w Narodowym Planie Rozwoju na lata 2004-2006 r. przeznaczono znaczne środki na rozwój instytucji otoczenia biznesu (Marciniec 2007). Coraz więcej samorządów lokalnych, jednostek naukowo-badawczych oraz prywatnych inwestorów dostrzegało korzyści płynące $z$ funkcjonowania już istniejących parków, a łatwiejszy dostęp do funduszy stał się katalizatorem podjęcia decyzji o ulokowaniu parku na swoim terenie. W ciagu kilku ostatnich lat tendencja do powoływania instytucji typu parkowego nieco osłabła. Jednakże liczba tworzonych parków nadal utrzymywała się na wysokim poziomie.

Od 2006 do 2008 r. powstało czternaście parków. W 2008 r. w Polsce istniały już 52 instytucje typu parkowego, z czego $46 \%$ stanowiły instrumenty pomocy publicznej o typowej działalności proinnowacyjnej (parki technologiczne i naukowo-technologiczne) (ryc. 3).

Należy zwrócić uwagę, że część z powołanych w 2008 r. parków nie rozpoczęła jeszcze działalności. W przypadku tych najnowszych sytuację wiązać należy z krótkim czasem przeznaczonym na ich organizację, unormowanie spraw formalno-prawnych gruntów i nieruchomości, czy pozyskanie firm chętnych do współpracy. Istniały jednak parki, które od kilku lat nie zdołały rozpocząc działalności. Taki stan rzeczy wynika ze złego oszacowania potencjału gospodarczego i naukowego regionu lub słabego marketingu i zarządzania parkiem (Matusiak, Mażewska 2004).

W pierwszych latach rozwijania sieci instytucji innowacyjnych w Polsce parki technologiczne i naukowo-technologiczne lokowano w dużych ośrodkach miejskich, o ugruntowanych tradycjach akademickich. Tendencja taka zgodna była ze światowymi trendami. Według badań prowadzonych przez Międzynarodowe Stowarzyszenie Parków Naukowych (IASP) jedna czwarta parków działających na świecie znajdowała się w miastach metropolitalnych. Stwierdzono również, że 76\% światowych parków funkcjonowało w bezpośrednim sąsiedztwie uniwersytetu (Furtak 2004). W miarę upływu czasu siła ciężkości lokalizacji polskich parków związanych z technologią przesuwała się ku miastom o niższym potencjale ludnościowym, gospodarczym i związanych z mniej prestiżowymi placówkami akademickimi. W ten sposób w przyszłości na terenie Polski stanie się możliwe utworzenie spójnej sieci instytucji innowacyjnych.

Odmiennymi przesłankami rządziło się lokalizowanie parków przemysłowych i przemysłowo-technologicznych. Instytucje te od początków swojej działalności w Polsce sytuowane były zazwyczaj w miastach średniej wielkości, gdzie rozwiązywać miały lokalne problemy restrukturyzacji. 


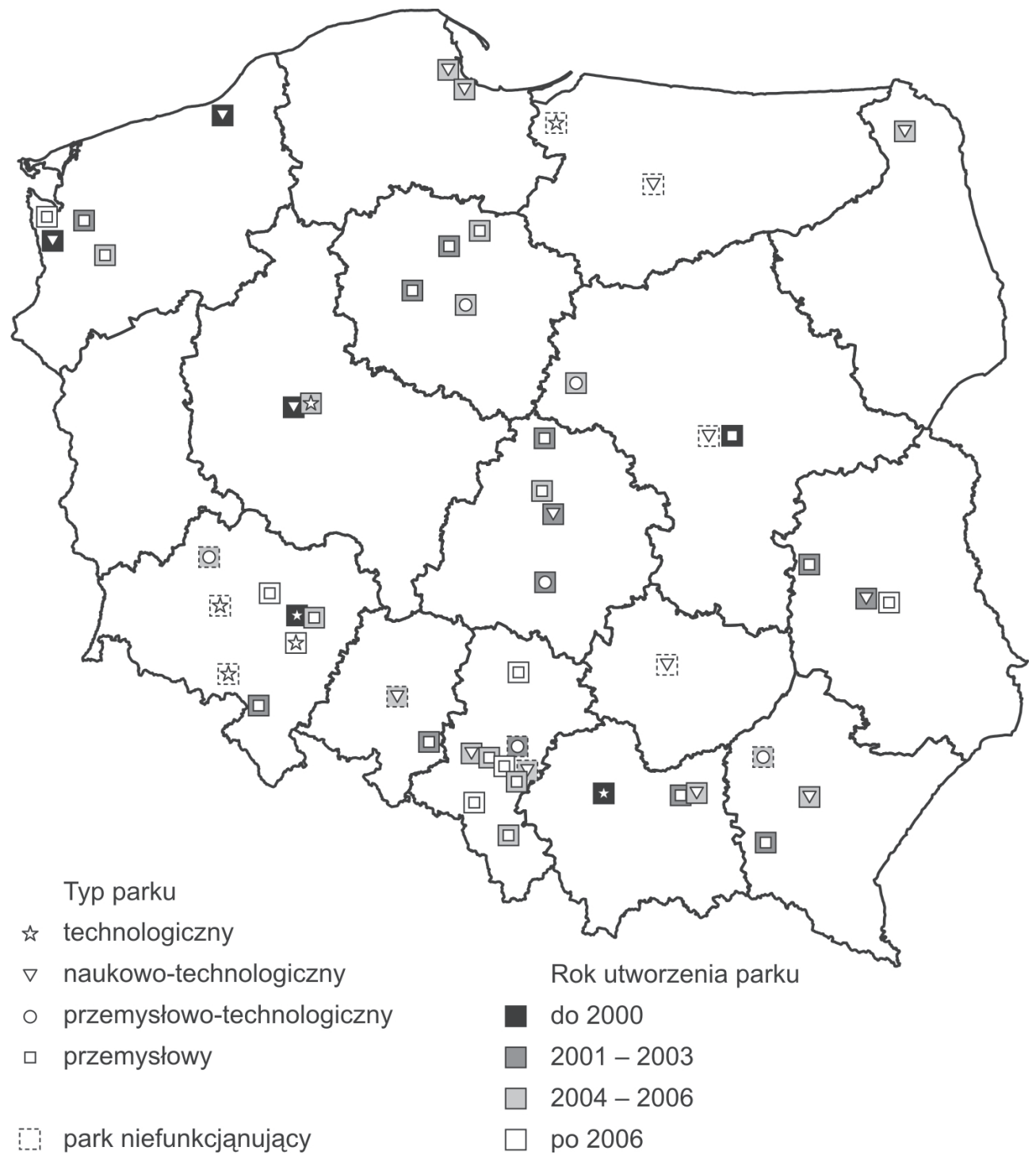

Ryc. 3. Instytucje parkowe w Polsce w 2008 r.

Źródło: Opracowanie własne na podstawie Mackiewicza (2008), Matusiaka (2007) i stron internetowych

Rozmieszczenie instytucji typu parkowego w Polsce w 2008 r. wykazuje znaczne przestrzenne zróżnicowanie (ryc. 3). Koncentracja tego typu instytucji ma miejsce na obszarze województwa śląskiego i dolnośląskiego. Najrzadziej parki technologiczne są rozmieszczone w województwach: podlaskim i świętokrzyskim. Brak ich jest w województwie lubuskim.

Przyczyny tworzenia parków w poszczególnych regionach Polski były silnie zróżnicowane (ryc. 4). Najczęściej wskazywanym celem działalności parków było utworzenie no- 


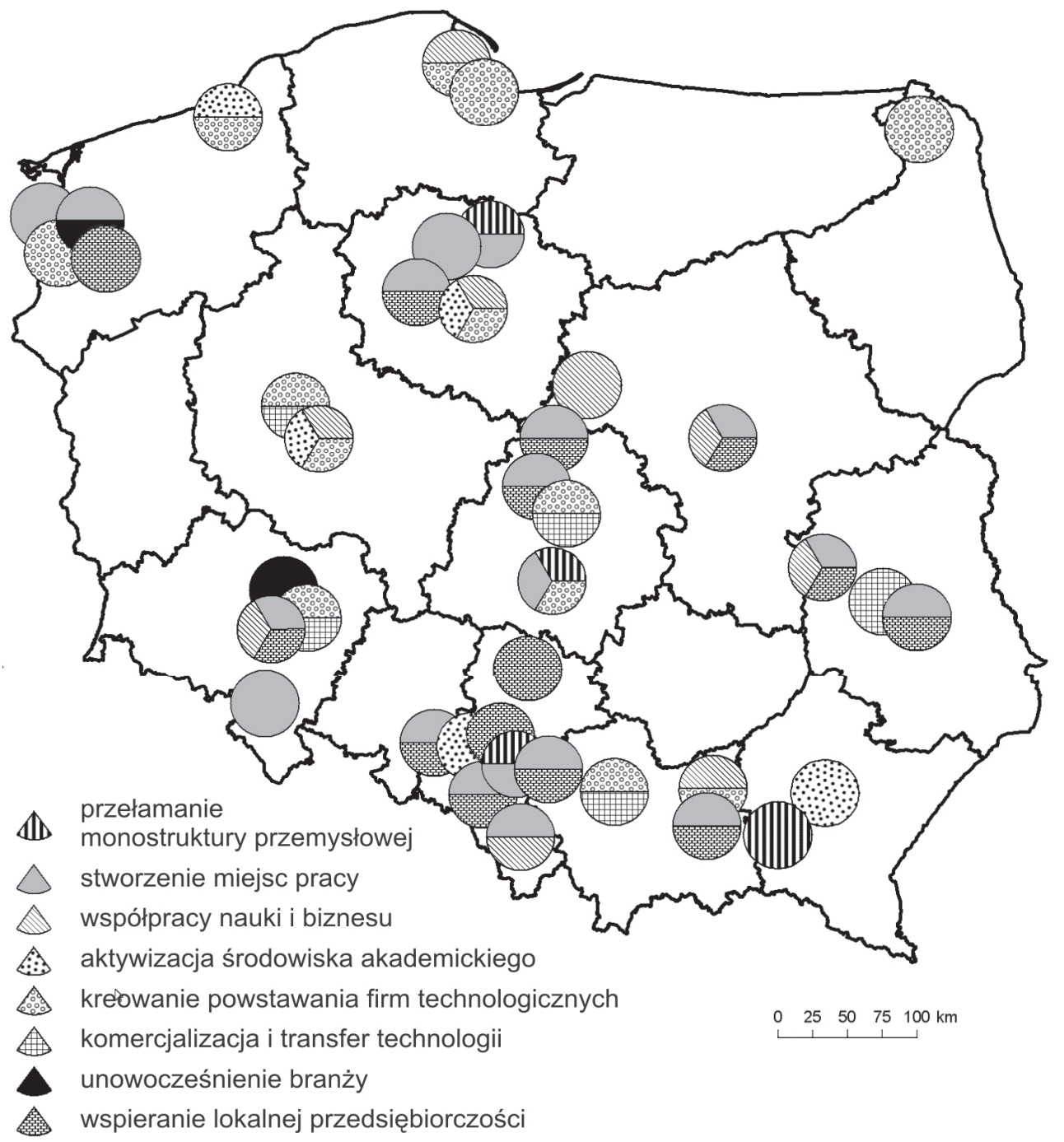

Ryc. 4. Przyczyny powołania parków w Polsce

Źródło: Opracowanie własne na podstawie Mackiewicza (2008) i stron internetowych

wych miejsc pracy. Ten cel w 2007 r. był charakterystyczny dla ponad 26\% omawianych instytucji. Na drugiej pozycji ulokowała się kategoria dotycząca wspierania lokalnej przedsiębiorczości (20\% parków). Taki rozkład wymienionych celów powoływania polskich parków związany był z ich strukturą typologiczną. Dominującym rodzajem w 2007 r. były parki przemysłowe, które stanowiły aż 55\% ogółu wszystkich parków funkcjonujących w Polsce. We wspomnianych parkach główne przyczyny ich istnienia związane były ze stworzeniem miejsc pracy (45\% parków przemysłowych) oraz wspieraniem lokalnej przedsiębiorczości (35\% omawianych parków). Bardzo często obie wymienione kategorie celów działalności współistniały ze sobą. $\mathrm{O}$ wiele rzadziej parki przemysłowe powoływane były w celu prze- 
łamania monostruktury przemysłowej lub unowocześnienia konkretnego rodzaju produkcji. Sytuacja taka pojawiała się tylko w ośrodkach o ugruntowanej tradycji jednej gałęzi przemysłu, na przykład w Katowicach, Grudziądzu i Brzegu Dolnym.

Wśród parków technologicznych przeważały te, które jako jeden z głównych celów swojej aktywności deklarowały tworzenie warunków dla powstawania nowych firm technologicznych. W 2007 r. było to aż 43\% z omawianych parków. Innym, często pojawiającym się celem działalności tych instytucji, była komercjalizacja i transfer technologii $(29 \%$ parków technologicznych). Poza tym parki te powoływano w celu aktywizacji środowiska akademickiego oraz realizowania założeń współpracy nauki z biznesem.

Zwraca uwagę wysoki odsetek parków (43\% ogółu tych instytucji w Polsce), które nie deklarowały żadnej specjalizacji branżowej (ryc. 5). Udział tzw. parków ogólnych w światowej populacji instytucji parkowych najczęściej kształtuje się na poziomie 25-27\% (Marciniec 2007). Wysoki udział w Polsce parków bez żadnej specjalizacji branżowej może wpływać negatywnie na funkcjonowanie i realizację celów, dla których parki te zostały powołane. Powyższa sytuacja może skutkować bardzo zróżnicowanymi i często odmiennymi oczekiwaniami lokatorów parków wobec tych instytucji.

Wśród parków ukierunkowanych specjalistycznie w 2007 r. najczęściej pojawiała się branża ITC (informatyka i telekomunikacja). Taka działalność firm-lokatorów występowała w $1 / 3$ omawianych instytucji. W wypadku parków technologicznych stanowiła ona nawet 3/4 ogółu ulokowanych firm. Inne popularne branże podmiotów lokujących się w parkach to: biotechnologiczna, elektroniczna i elektromaszynowa, każda obejmująca $13 \%$ z omawianych instrumentów pomocy publicznej. W wypadku parków technologicznych wspomniane branże uzyskują wyższe wartości.

Struktura branżowa polskich parków nie odbiegała od standardów światowych. Według badań ISAP parki światowe w głównej mierze zajmowały się branżą ITC (26\%). W dalszej kolejności lokowała się w nich branża biotechnologiczna (20\%) i elektroniczna (19\%). Znaczny odsetek parków przyciągał też przedsiębiorstwa farmaceutyczne (Furtak 2004).

Szczególną rolę w procesie unowocześniania gospodarki odgrywają parki technologiczne. Wskazane instytucje prorozwojowe przygotowują niezbędną dla funkcjonowania przedsiębiorstw infrastrukturę oraz pewne szczególne elementy wyposażenia terenu, przydatne dla firm zajmujących się nowymi technologiami oraz kreujących innowacje. Ponadto instytucje te zajmują się działalnością doradczą w różnych dziedzinach. Proponują pomoc w zarządzaniu zasobami ludzkimi, finansowymi i rzeczowymi, szeroko rozumianym marketingu, a także obsługę prawną i księgową. Dla przedsiębiorstw opracowujących nowe produkty i usługi przewidziana została pomoc w uzyskaniu patentów i rejestracji znaków towarowych. Tym firmom, których działalność wymaga zakupu technologii, proponowana jest pomoc w zawarciu transakcji. Parki technologiczne mogą pośredniczyć w pozyskaniu przez firmy grantów, dotacji, dopłat oraz oferują obsługę funduszy pożyczkowych i poręczeniowych. Dodatkowo omawiane instrumenty pomocy publicznej są miejscem, gdzie młode firmy nieposiadające znacznych środków finansowych na swoją działalność spotykają się i nawiązują współpracę ze spółkami venture capital oraz tzw. aniołami biznesu, czyli osobami fizycznymi finansującymi działalność innowacyjnych firm w fazie ich rozruchu (Drozdowska 2009).

Pomiędzy poszczególnymi parkami technologicznymi w Polsce w 2007 r. istniały znacznie różnice pod względem zajmowanej powierzchni. Dominowały parki małe o powierzchni poniżej 1 ha. Tylko trzy parki technologiczne w Polsce można było zaliczyć do 


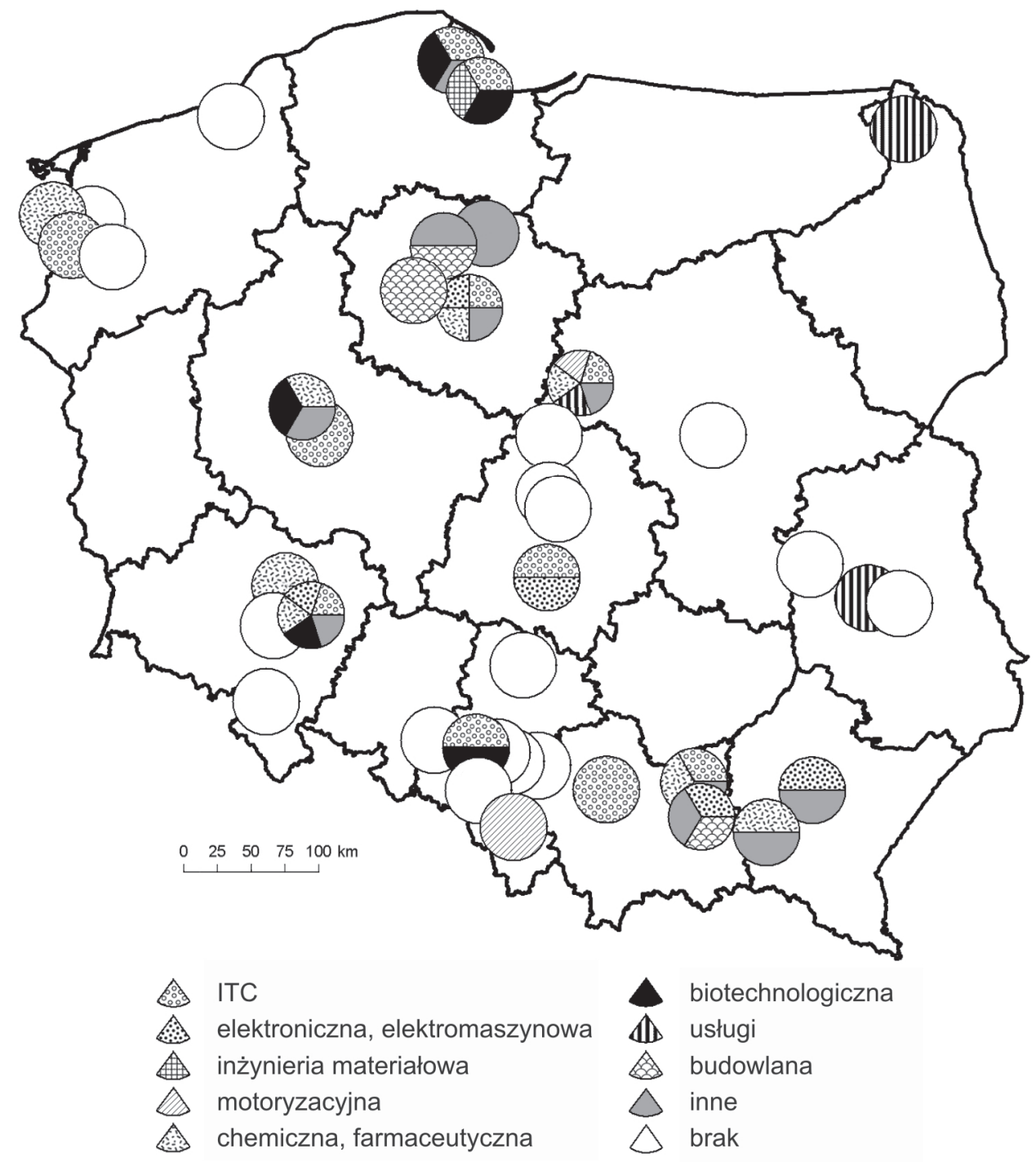

Ryc. 5. Specjalizacja branżowa parków w $2007 \mathrm{r}$.

Źródło: Opracowanie własne na podstawie Mackiewicza (2008) i stron internetowych

kategorii dużych, zajmujących powierzchnię powyżej 100 ha (Bełchatowsko-Kleszczowski, Krakowski i Płocki).

W 2007 r. w polskich parkach technologicznych ulokowanych było łącznie 359 podmiotów. Najwięcej podmiotów znalazło się w parku Wrocławskim (59) i Poznańskim (30), a więc w tych najstarszych. Wskazane parki, obok Krakowskiego Parku Technologicznego, Gdańskiego Parku Naukowo-Technologicznego oraz Bełchatowsko-Kleszczowskiego Parku Przemysłowo-Technologicznego charakteryzowały się jednocześnie największą różnorodnością ulokowanych podmiotów (ryc. 6A). W większości parków technologicznych zwraca 

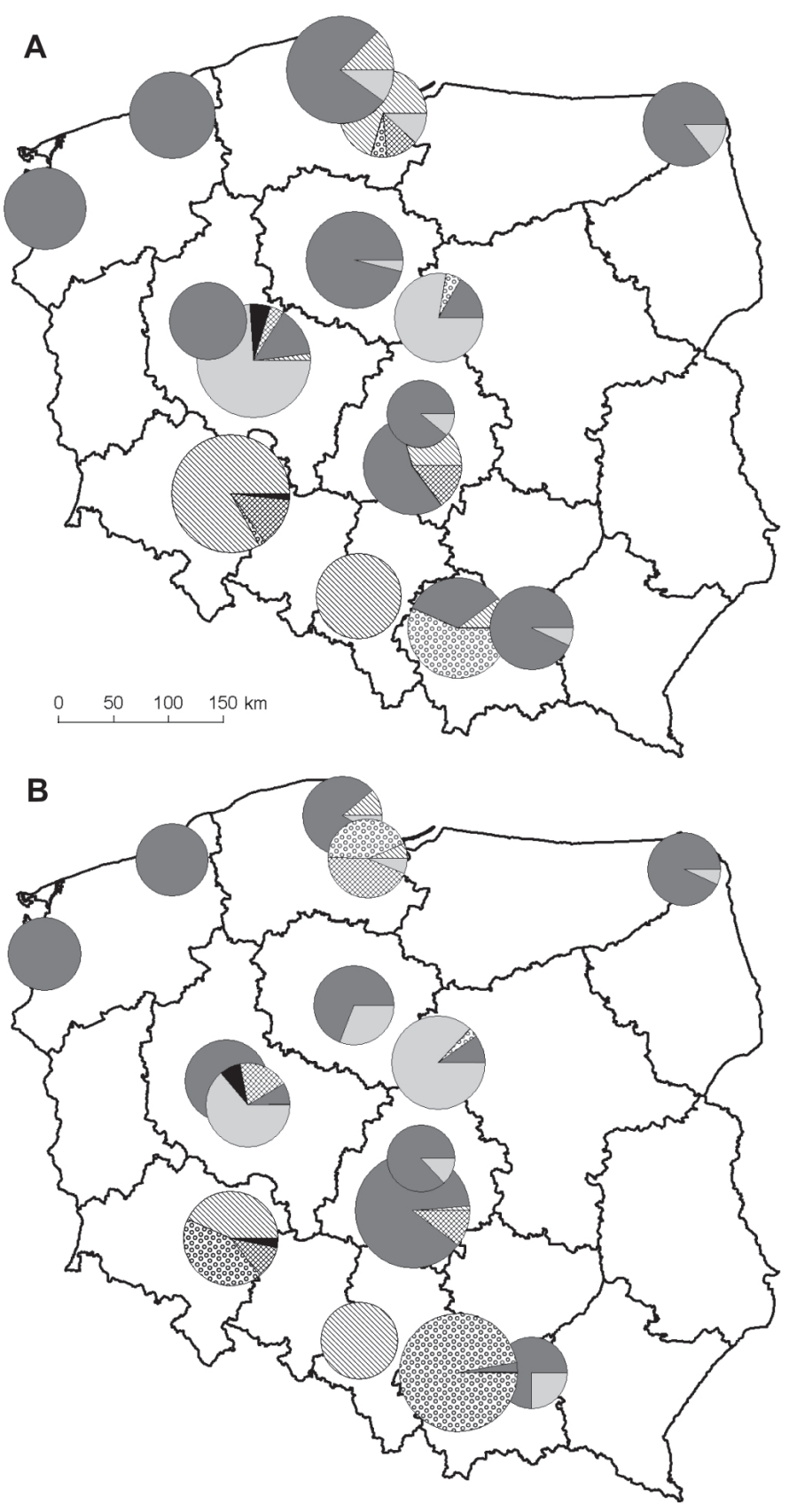

Ryc. 6. Struktura podmiotów według ich liczby (A) i zatrudnienia (B) w parkach technologicznych w $2007 \mathrm{r}$.
Liczba podmiotów

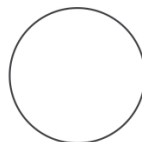

60

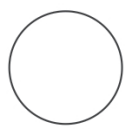

30<smiles>C1CCCCCC1</smiles>

10

Typ podmiotu

make firmy technologiczne

inne MSP

inwestorzy strategiczni

firmy zagraniczne

instytucje $B+R$

inne instytucje

\section{Liczba zatrudnionych}

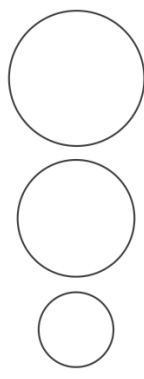


uwagę duży udział firm z sektora MSP, niekoniecznie związanych z nowoczesnymi technologiami (wyjątek stanowią parki: Wrocławski, Poznański, Gdański czy Gliwicki). Istotnym problemem parków technologicznych w Polsce był praktycznie brak na ich obszarze (z wyjątkiem Poznańskiego i Wrocławskiego) instytucji badawczo-rozwojowych. Biorąc pod uwagę fakt, iż wspomniane instytucje prorozwojowe mają być w założeniu generatorami innowacji i unowocześnienia polskiej gospodarki, brak instytucji $\mathrm{B}+\mathrm{R}$ na ich obszarach jest wysoce niezadowalający.

Parki technologiczne mają wpływ na rynek pracy. Łączna liczba osób zatrudnionych w polskich parkach technologicznych w 2007 r. wynosiła 9161. Zwrócić należy uwagę, że zatrudnienie to rozkładało się bardzo nierównomiernie pomiędzy poszczególnymi parkami. Największe zatrudnienie było w Bełchatowsko-Kleszczowskim Parku PrzemysłowoTechnologicznym i Krakowskim Parku Technologicznym. Łącznie zatrudnieni w podmiotach funkcjonujących na terenie obu parków stanowili 60\% ogółu zatrudnionych w firmach zlokalizowanych w parkach technologicznych w Polsce (ryc. 6B).

Polskie parki technologiczne charakteryzowały się ponadto znacznym zróżnicowaniem w zakresie liczby i typów usług oferowanych lokatorom. Najbardziej rozwinięte były usługi doradcze (z zakresu zarządzania i marketingu, technologiczno-patentowe, finansowo-prawne), gdyż występowały w każdym z omawianych parków. Dość dobre było wyposażenie w urządzenia infrastrukturalne (udostępnianie sprzętu, sal seminaryjnych). Trudniejsza sytuacja miała miejsce w wypadku laboratoriów. Tylko w połowie parków lokatorzy mogli korzystać z tego typu infrastruktury. Najsłabiej reprezentowane były usługi finansowe (obsługa funduszy pożyczkowych, lub/i poręczeniowych, subwencje, granty i dopłaty, venture capital) (Mackiewicz 2008), niezbędne przy realizacji przedsięwzięć innowacyjnych i technologicznych. Ich brak rodzi wątpliwości co do skuteczności parków technologicznych $\mathrm{w}$ procesie unowocześniania gospodarki, tym bardziej że wykazują się one niską aktywnością w zakresie komercjalizacji technologii, rejestracji znaków towarowych i zgłoszeń patentowych - miały one miejsce jedynie w 20\% parków. Najpopularniejszą formą omawianej działalności było umieszczenie na terenie parku inkubatora. Funkcjonowały one w $60 \%$ omawianych instytucji. W pozostałych $20 \%$ parków nie prowadzono żadnych działań z zakresu komercjalizacji i transferu technologii.

Poważną barierą systemową dla rozwoju inicjatyw parków naukowo-technologicznych i innych instytucji proinnowacyjnych (pośredniczących) jest także niska intensywność współpracy uczelni z przemysłem, komercjalizacji badań i powstawania nowych firm technologicznych i odpryskowych (spin-offs). Pomijając ogólne, często niekorzystne uwarunkowania dla rozwoju przedsiębiorczości, istotnym ograniczeniem jest także niedorozwój instrumentów finansowania nowych firm technologicznych, czyli funduszy zalążkowych (seed capital), czy sieci osób fizycznych inwestujących na rynku venture capital (Raport końcowy... 2005).

\section{PrZestrzenne ZRÓŻNicowanie Instytucji typu inkubatorowego w Polsce}

Instytucje parków i inkubatorów technologicznych odpowiadają spełnianej przez nie roli inspiratora współpracy, zarówno między przedsiębiorstwami a sferą nauki, jak i między przedsiębiorstwami. Wszystkie definicje parków technologicznych i inkubatorów kładą na- 
cisk na ułatwianie przedsiębiorcom kontaktów z ośrodkiem naukowym, jako jedną z głównych funkcji. Wsparcie współpracy przedsiębiorstw następuje w sposób naturalny - poprzez gromadzenie na jednym terenie wielu firm o podobnym profilu, czy też firm danego sektora. Podstawowa różnica między inkubatorem a parkiem technologicznym to zakres wsparcia, jaki otrzymują przedsiębiorcy. Rola parku polega przede wszystkim na zapewnieniu odpowiedniej lokalizacji dla firm technologicznych i innowacyjnych na danym terenie. W tym zakresie parki działają często w formule komercyjnej. $\mathrm{Z}$ tego też powodu gromadzą one zazwyczaj firmy dojrzałe, które akceptują rynkowe stawki czynszu (a czasem nawet wyższe), w zamian za możliwość korzystania z infrastruktury i uczestniczenia w specyficznym i konkurencyjnym otoczeniu, jakie wytwarza się na terenie parku. Inkubator technologiczny ma natomiast wspierać powstawanie nowych firm technologicznych - stąd warunki korzystania z niego są częściej preferencyjne (jakkolwiek w ograniczonym okresie czasu) - i zwiększyć szanse utrzymania się firm na rynku. Dlatego inkubatory są często tworzone na obszarze parków technologicznych. Nieco inny charakter mają inkubatory przedsiębiorczości - mają one na celu wspieranie małej i średniej przedsiębiorczości ze wszystkich dziedzin gospodarki, stanowiąc raczej element polityki rynku pracy i przeciwdziałania bezrobociu (Parki technologiczne... 2008).

Zarówno dla inkubatorów, jak i dla parków możliwość uzyskania pomocy publicznej związana jest z priorytetem 1.3 SPO WKP. Ze środków w ramach tego priorytetu mogą być realizowane inwestycje $\mathrm{w}$ inkubatorach i parkach technologicznych oraz doradztwo dla jednostek zarządzających. W ramach Działania 1.3. SPO WKP możliwe jest finansowanie projektów polegających na (Wojnicka 2005):

- instalacjach technologicznych wynikających ze specyficznego charakteru inkubatora technologicznego,

- inwestycjach w budowle i budynki,

- obsłudze administracyjno-biurowej firm,

- atrakcyjnych cenowo warunkach lokalowych,

- doradztwie biznesowym (prawnym, finansowym, patentowym itp.),

- szkoleniach,

- promocji firm działających w inkubatorze,

- dostępie do laboratoriów i bibliotek lokalnej instytucji naukowej o profilu technicznym,

- sprzyjającym środowisku dla przedsiębiorców.

W polskich warunkach najbardziej popularny jest typ inkubatora związany z aktywizacją przedsiębiorczości. Inkubatory technologiczne pojawiają się znacznie rzadziej. Na koniec 2007 r. w Polsce funkcjonowało 47 inkubatorów przedsiębiorczości i 16 inkubatorów technologicznych. Największa ich liczba występowała w województwach: śląskim, łódzkim i zachodniopomorskim. Najrzadziej występowały natomiast w Polsce północno-wschodniej (ryc. 7). Biorąc pod uwagę konieczność aktywizacji gospodarczej i wzrost poziomu przedsiębiorczości tej części Polski, wydaje się, że liczba instytucji prorozwojowych na tych obszarach jest niewystarczająca. Dodatkowo liczne inkubatory zlokalizowane w Polsce południowej i zachodniej mogą pogłębiać różnicę w rozwoju społeczno-gospodarczym pomiędzy wskazanymi obszarami naszego kraju.

Instytucje typu inkubatorowego nie są nastawione na osiąganie zysków ze swojej działalności. Jednakże ich funkcjonowanie powinno być samowystarczalne. Przychody z działalności muszą wystarczyć na zakup niezbędnego sprzętu, organizację kursów i szkoleń oraz 


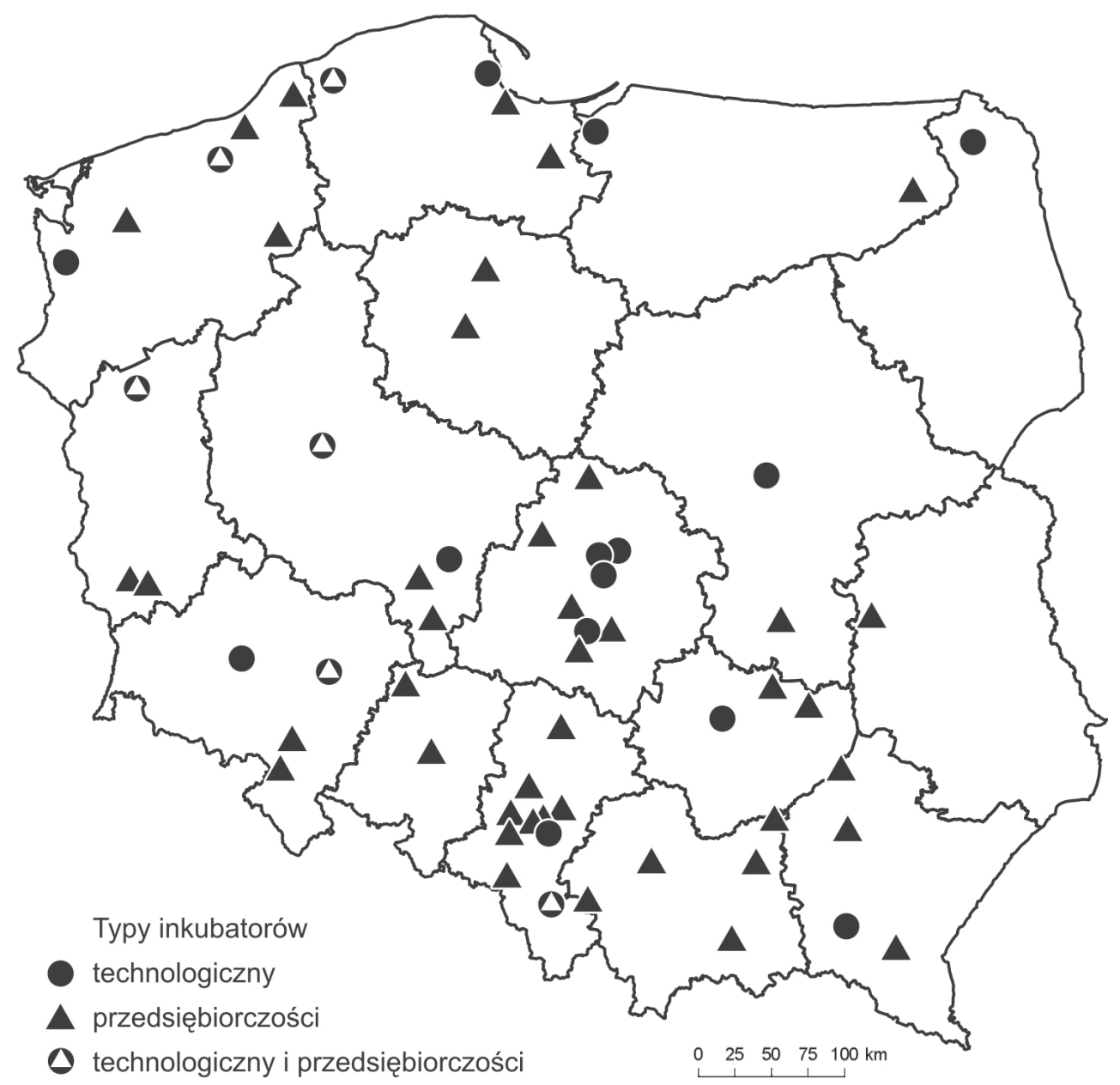

Ryc. 7. Inkubatory w Polsce w 2007 r.

Źródło: Opracowanie własne na podstawie Matusiaka (2007), Gulińskiego (2008) i stron internetowych

doradztwa. Wśród przychodów polskich inkubatorów technologicznych i przedsiębiorczości w 2007 r. dominowały wpływy z czynszu i innych opłat. Stanowiły one ponad połowę wszystkich przychodów. Znaczna pula środków na działalność inkubatorów, bo około jednej czwartej, pochodziła z grantów i projektów celowych (ryc. 8). Konstrukcja finansowa tych instytucji powoduje, że priorytetem wydatkowania pomocy publicznej w inkubatorach jest stworzenie bazy dla działalności firm-lokatorów i jej wyposażenie. Drugorzędne stają się działania mające istotne znaczenie w uzyskiwaniu siły rynkowej powstających firm technologicznych, ukierunkowane na szkolenia i rozwój wyspecjalizowanych usług. Potwierdza to struktura wydatkowania pomocy publicznej w inkubatorach (ryc. 9).

W 2007 r. inkubatory przedsiębiorczości zasiedlało łącznie ponad 700 podmiotów, w których pracowało ok. 3 tys. osób. Największym pod tym względem był Słupski Inkubator Przedsiębiorczości, liczący 48 lokatorów. Jest on przykładem istotnego wpływu inkubatora 


\section{INKUBATORY \\ PRZEDSIĘBIORCZOŚCI}

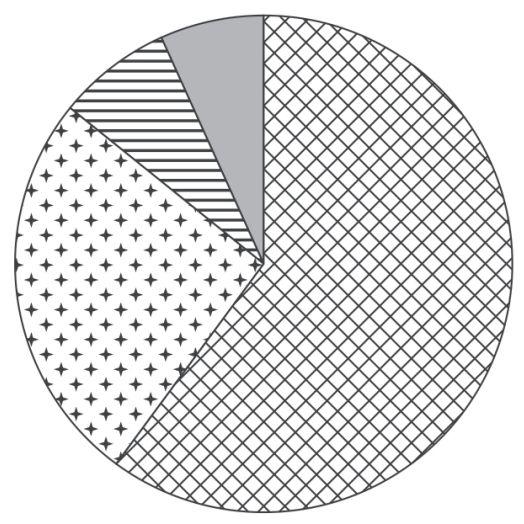

wpływy z czynszu i innych opłat $+_{+}^{+}+$granty i projekty celowe

\section{INKUBATORY TECHNOLOGICZNE}

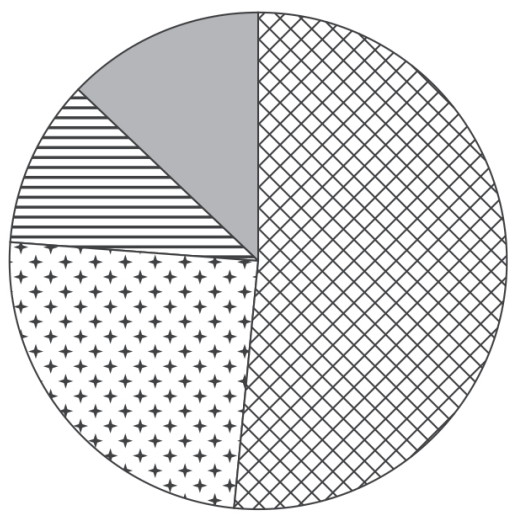

E inne przychody własne pozostałe

Ryc. 8. Struktura przychodów inkubatorów w 2007 r.

Źródło: Opracowanie własne na podstawie Matusiaka (2007)

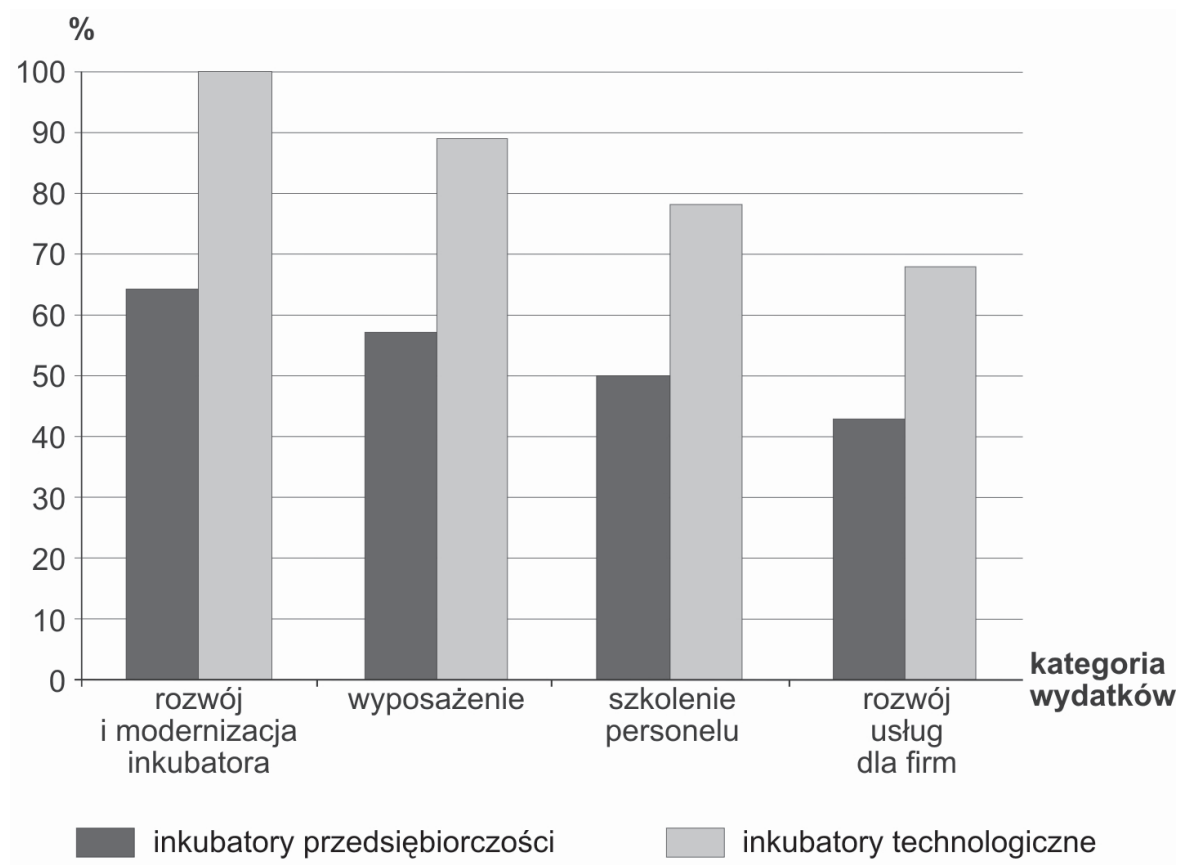

Ryc. 9. Kierunki wykorzystania środków pomocy publicznej w inkubatorach w $2007 \mathrm{r}$.

Źródło: Opracowanie własne na podstawie Matusiaka (2007) 


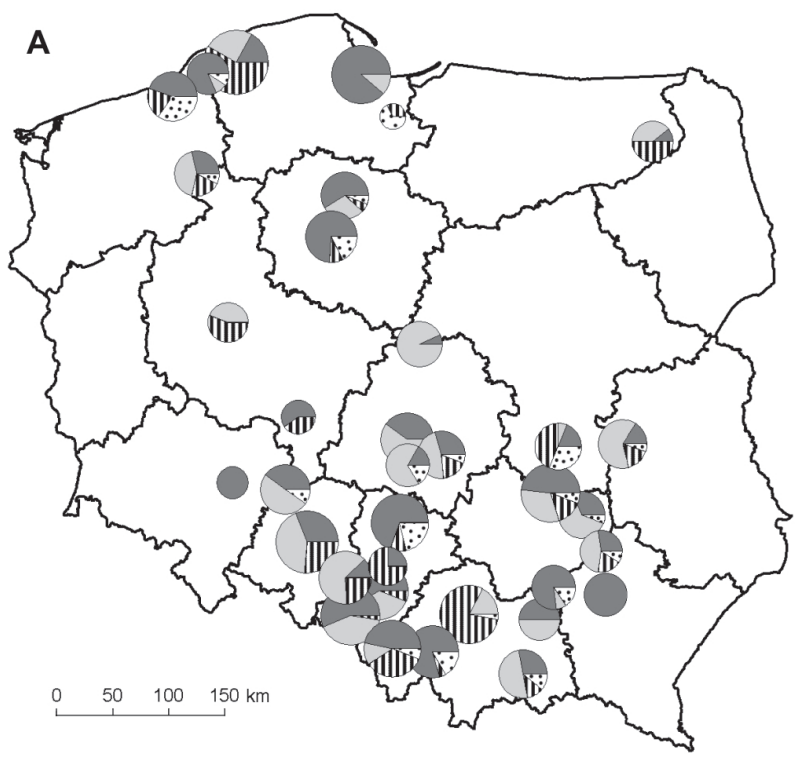

Liczba podmiotów

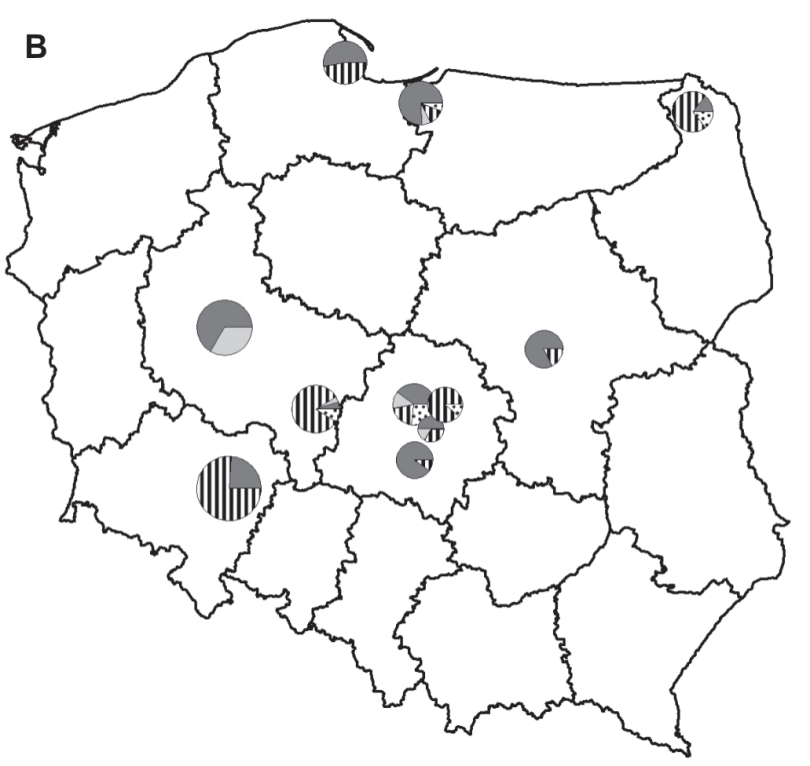

Liczba podmiotów

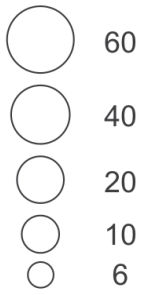

Ryc. 10. Liczba i struktura podmiotów w inkubatorach przedsiębiorczości (A) i technologicznych (B) w 2007 r.

Źródło: Opracowanie własne na podstawie Matusiaka (2007) i stron internetowych

na restrukturyzację i aktywizację lokalnych gospodarek w obszarach problemowych (w tym wypadku przemysłu maszynowego i uspołecznionego rolnictwa w regionie słupskim).

Inkubatory przedsiębiorczości najczęściej występują w środkowo-południowej Polsce (ryc. 10A). Zwraca uwagę znaczny udział wśród ich lokatorów firm nowo powstających, co jest zrozumiałe z punktu widzenia istoty powoływania inkubatorów. Ważną rolę w funk- 
cjonowaniu inkubatorów przedsiębiorczości i technologicznych odgrywają również tzw. lokatorzy strategiczni (ryc. 10B). Są to firmy o już ugruntowanej pozycji na rynku i skłonne płacić maksymalne stawki czynszu. Dla inkubatorów stanowią one główne źródło dochodów (ryc. 8).

Inkubatory technologiczne znacznie rzadziej występują w polskiej przestrzeni gospodarczej. Ich rozkład przestrzenny jest uwarunkowany przede wszystkim koniecznością występowania w bezpośrednim otoczeniu szerokiego i dobrze wykształconego zaplecza naukowego, które dostarczają duże aglomeracje miejskie (łódzka, wrocławska, poznańska, trójmiejska, warszawska). Łącznie na obszarze parków technologicznych funkcjonowało w 2007 r. ponad 200 podmiotów, które zatrudniały około 1300 osób. Największe parki technologiczne to: wrocławski, poznański i pomorski. Najmniejsze zaś były zlokalizowane na obszarze województwa łódzkiego (ryc. 10B).

W warunkach polskich inkubatory technologiczne ze skromnym zapleczem naukowo-badawczym nie mają jeszcze na tym etapie swojego rozwoju wielkiej szansy na odegranie istotnej roli pomostu między sferą badań a przemysłem, choć bez wątpienia spełniają funkcję inicjatora takiej współpracy. W wypadku inkubatorów przedsiębiorczości, przyciaganie i skupianie firm sprzyja wzrostowi przedsiębiorczości oraz poprawie sytuacji lokalnych gospodarek.

\section{WPLYW INSTYTUCJI PROROZWOJOWYCH ZWIĄZANYCH Z POMOCĄ PUBLICZNA}

\section{NA AKTYWIZACJĘ POLSKIEJ GOSPODARKI}

Pomoc publiczna nie jest przyznawana równomiernie wszystkim regionom państwa. $\mathrm{Z}$ założenia powinna się koncentrować na obszarach problemowych. W Polsce takimi obszarami są te, które wymagają restrukturyzacji, aktywizacji bądź obarczone są wysokim bezrobociem, depopulacją czy dekapitalizacją majątku trwałego. Restrukturyzacja starych okręgów przemysłowych, zainicjowana w latach 90. XX w., skoncentrowała się m.in. na Górnośląskim Okręgu Przemysłowym, Dolnośląskim Zagłębiu Węglowym, Łódzkim Okręgu Włókienniczym czy obszarach związanych z przemysłem stoczniowym. W tych regionach konieczne jest unowocześnienie istniejących oraz wprowadzenie nowych, bardziej zaawansowanych technologicznie gałęzi gospodarki. Tylko takie rozwiązanie umożliwi wzrost roli wymienionych obszarów na europejskich i światowych rynkach.

Inną grupa polskich regionów problemowych jest północna i północno-wschodnia część kraju - dawne obszary rolnictwa uspołecznionego i niskiej aktywności gospodarczej. Dodatkowy problem stanowi brak na tych obszarach odpowiednio wykwalifikowanej siły roboczej. Stąd w 2007 r. utrzymywał się w nich wysoki poziom bezrobocia, niskiej przedsiębiorczości i kreatywności. Ponadto w 2007 r. cała wschodnia część Polski wykazywała niższy poziom rozwoju gospodarczego w porównaniu z innymi częściami kraju, a także regionami Unii Europejskiej. Problem stanowiło zatrudnienie zbyt dużej części ludności w rolnictwie i słaby rozwój sektora usług.

Wydawać by się mogło, że w tak zarysowanej przestrzeni łatwo określić miejsca pojawienia się instrumentów pomocy publicznej. Tymczasem przestrzenny obraz rozmieszczenia instrumentów pomocy publicznej w Polsce jest bardziej złożony. Intensywność pomocy publicznej została wyrażona liczbą instytucji prorozwojowych z nią związanych w powiecie. 
Pierwszy zbiór (o dużej pomocy publicznej) stanowiły jednostki, na terenie których wystąpiły równocześnie: podstrefa specjalnej strefy ekonomicznej, park i inkubator. Do tej zbiorowości zaliczono także powiaty, na obszarze których brakowało którejś z wymienionych form, ale jedna z pozostałych dwóch pojawiła się częściej niż jeden raz. Drugi zbiór (o małej pomocy publicznej) stanowiły powiaty, w których obserwowano jedną lub dwie z trzech wyróżnionych form pomocy publicznej. Trzecią grupę tworzyły powiaty, gdzie nie występowała żadna z opisanych form pomocy publicznej. Do określenia intensywności pomocy publicznej włączono także specjalne strefy ekonomiczne, mimo że nie były one przedmiotem opracowania. Jednak określenie samego wpływu instytucji parkowych i inkubatorowych na gospodarkę na tym etapie ich rozwoju jest niemożliwe. Ten wpływ należy rozpatrywać w kontekście całości pomocy publicznej obejmującej także SSE.

Instytucje prorozwojowe związane z pomocą publiczną występowały $\mathrm{w} 43 \%$ polskich powiatów (ryc. 11). W rezultacie około $40 \%$ powierzchni kraju i ludności Polski związane było z różnymi kategoriami pomocy publicznej. Wyraźnie zarysowywał się brak instrumentów pomocy publicznej na terenach Polski wschodniej oraz w pasie powiatów od południowej części woj. zachodniopomorskiego przez północną część woj. wielkopolskiego, woj. kujawsko-pomorskie, po mazowieckie. Na tle całej Polski najsłabiej wypadało jednak województwo podlaskie, na obszarze którego tylko cztery powiaty posiadały jakiekolwiek instrumenty pomocy publicznej.

W odmiennej sytuacji znalazły się województwa: łódzkie i lubuskie. W 2007 r. prawie cały ich obszar podlegał oddziaływaniu pomocy publicznej. Ponadto województwa: śląskie, dolnośląskie i warmińsko-mazurskie w znacznej części związane były z omawianymi instrumentami.

$\mathrm{Z}$ przedstawionego rozmieszczenia instytucji prorozwojowych związanych z pomocą publiczną wynika, że uprzywilejowanymi obszarami w tym zakresie były województwa: śląskie, łódzkie czy dolnośląskie. Na terenach tych województw obserwowano największe natężenie i jednocześnie równomierny stopień pokrycia ich obszarów różnymi formami pomocy publicznej. Taki rozkład omawianych organizacji pokrywał się z obszarami Polski, które wykazywały najwyższy poziom rozwoju gospodarczego, ale wymagały pewnego przemodelowania struktury, aby efektywniej funkcjonowały ich gospodarki.

Dyskusyjnym posunięciem wydaje się tworzenie przez państwo uprzywilejowanych warunków dla działalności gospodarczej w dużych miastach. Ze wszystkich typów omawianych organizacji tylko parki technologiczne i naukowo-technologiczne wymagają bliskości wyższych uczelni. Natomiast pozostałe formy bez przeszkód moga pojawiać się w innych lokalizacjach. Skumulowanie instrumentów pomocy publicznej w dużych ośrodkach miejskich może skutkować pojawieniem się efektu biegu jałowego. Atrakcyjność wielkomiejskich lokalizacji jest na tyle wysoka, że nawet bez zachęt inwestycyjnych w postaci pomocy publicznej osiedlają się tam podmioty gospodarcze, sprzyjając rozwojowi całej gospodarki.

Niewystarczająca jest liczba instrumentów pomocy publicznej na obszarach Polski wschodniej, słabiej rozwiniętej gospodarczo. Dla tych obszarów zachęty inwestycyjne mogłyby stanowić istotny bodziec rozwojowy. Tymczasem w 2007 r. na terenie województwa: podlaskiego, lubelskiego i w powiatach wokół aglomeracji warszawskiej notowano najmniejszą liczbę instytucji związanych z pomocą publiczną.

Próby określenia wpływu analizowanych instytucji związanych z pomocą publiczną na aktywizację gospodarki w jej układach regionalnych i lokalnych dokonano z zastosowaniem metody wskaźników przyrodniczych Perkala. W tym celu skonstruowano sześć wskaźników 


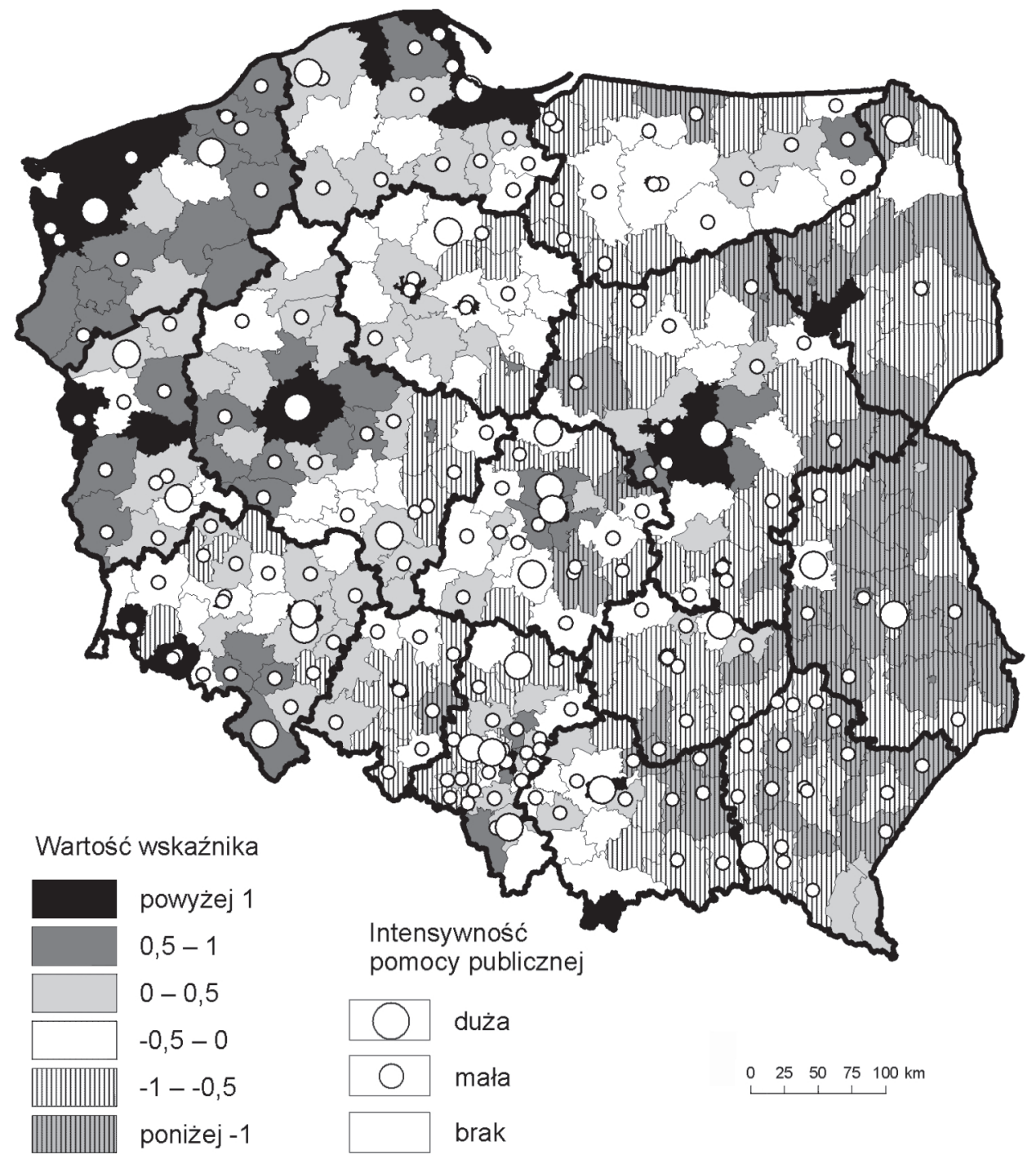

Ryc. 11. Poziom przedsiębiorczości i intensywność pomocy publicznej w 2007 r.

Źródło: Opracowanie własne na podstawie Banku Danych Regionalnych

cząstkowych, których konstrukcji dokonano na podstawie wyboru trzech charakterystycznych cech: przedsiębiorczości (liczba podmiotów gospodarczych, liczba nowych podmiotów gospodarczych oraz liczba osób prowadzących działalność gospodarczą do liczby mieszkańców); rynku pracy (odwrotność liczby długotrwale bezrobotnych, odwrotność stopy bezrobocia - opisujące ilościowo rynek pracy oraz odsetek zatrudnionych w usługach - oddający jego jakościowy charakter); otoczenia biznesu (liczba podmiotów pośrednictwa finansowego, liczba podmiotów obsługi nieruchomości i firm, liczba nowo utworzonych podmiotów tych sekcji do liczby mieszkańców); atrakcyjności (wysokości miesięcznego wynagrodzenia, 


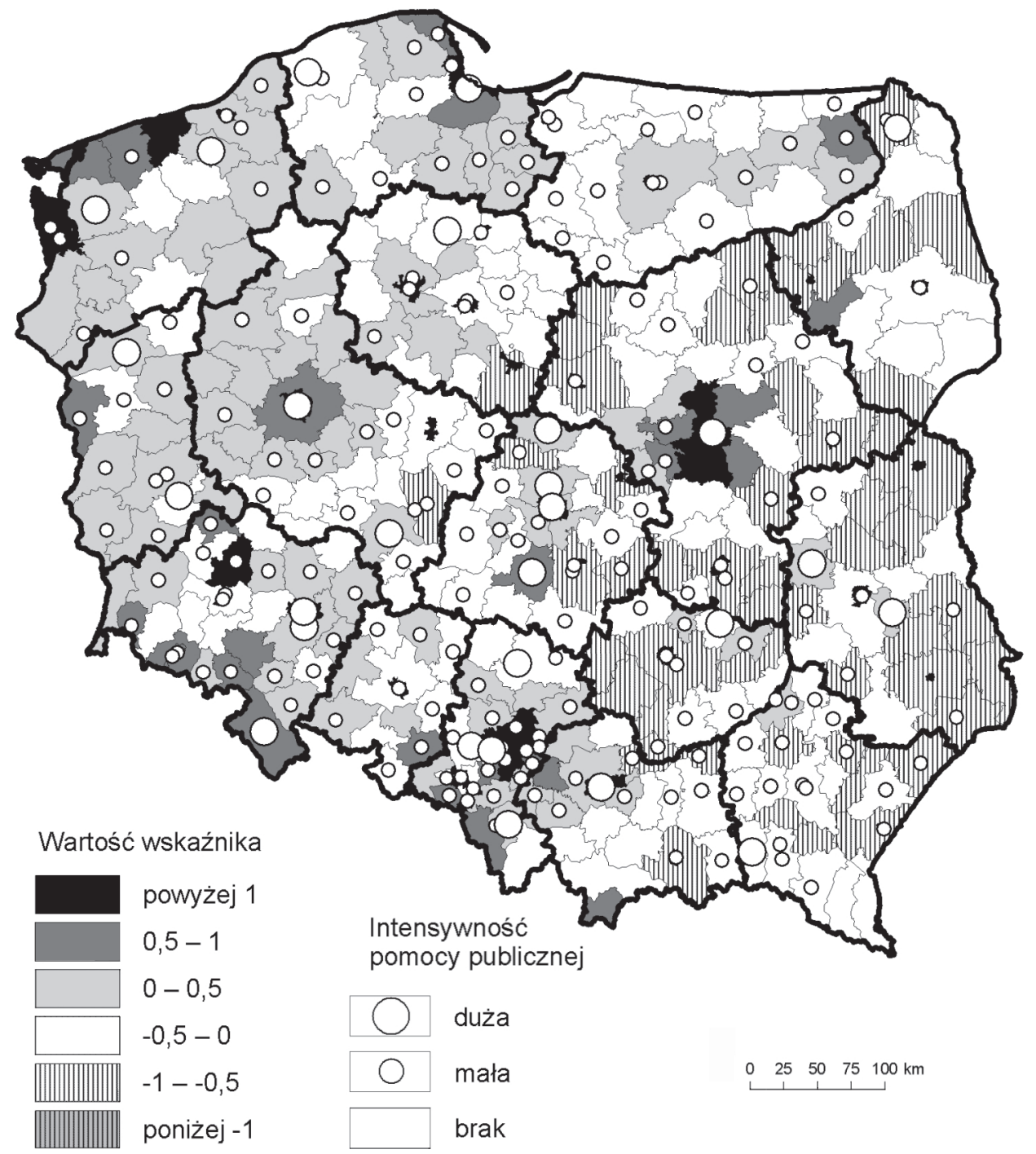

Ryc. 12. Poziom rozwoju społeczno-ekonomicznego i intensywność pomocy publicznej w 2007 r.

Źródło: Opracowanie własne na podstawie Banku Danych Regionalnych

liczba mieszkań oddanych do użytku oraz nakłady na ochronę środowiska do liczby ludności); infrastruktury (gęstości dróg o powierzchni twardej ulepszonej, gęstości sieci cieplnej oraz gęstości sieci kanalizacyjnej) i restytucji majątku trwałego (nakładów inwestycyjnych do liczby przedsiębiorstw, odwrotność stopnia zużycia maszyn i narzędzi oraz budynków i budowli). Wszystkie cechy były wskaźnikami o charakterze stymulanty. Na podstawie sześciu wskaźników cząstkowych obliczono wartość wskaźnika syntetycznego zmienności ogólnej rozwoju społeczno-gospodarczego. Następnie uzyskane wartości poszczególnych wskaźników cząstkowych i wskaźnika syntetycznego porównano z intensywnością pomocy 
publicznej w powiatach. Z uwagi na szeroki zakres analizowanych zjawisk w opracowaniu zaprezentowano tylko wybrane aspekty analizy (szerzej Drozdowska 2009).

Przestrzenne zróżnicowanie poziomu przedsiębiorczości nie wykazywało wyraźnego związku z rozmieszczeniem instytucji prorozwojowych (ryc. 11). Najwyższą przedsiębiorczością charakteryzowały się powiaty korzystające z pomocy publicznej, jak i te jej pozbawione. Podobna sytuacja miała miejsce w wypadku rynku pracy. Brak jest jednoznacznego związku występowania instytucji prorozwojowych z sytuacją na rynku pracy.

Pewne relacje przestrzenne są widoczne pomiędzy intensywnością pomocy publicznej a poziomem rozwoju społeczno-gospodarczego (ryc. 12). Najsilniej jest on widoczny w województwach: pomorskim, dolnośląskim, śląskim i małopolskim. Pewien pozytywny wpływ uwidacznia się także w wybranych powiatach województwa lubelskiego czy zachodniopomorskiego. Wobec powyższego można stwierdzić, iż analizowane instytucje prorozwojowe moga zwiększać intensywność aktywizacji powiatów o silnych gospodarkach i przyczyniać się do poprawy sytuacji w powiatach o niższym poziomie rozwoju gospodarczego, choć bez wątpienia ich liczba i wpływ na gospodarkę powiatów wschodniej i północno-wschodniej Polski jest niezadowalający.

\section{Podsumowanie}

Rozbudowa instytucji parkowych i inkubatorowych może nieść ze sobą skutki ekonomiczne na trzech płaszczyznach. Na poziomie regionu przyczynia się do wzrostu konkurencyjności lokalnej gospodarki i wzrostu udziału dóbr i usług wysokiej technologii w strukturze produkcji. Na poziomie przedsiębiorstw tworzone są nowe miejsca pracy i inwestycji w działalność badawczo-rozwojową, innowacyjność i akumulację kapitału ludzkiego. Na poziomie ośrodków naukowych skutkuje zmianą kierunków prowadzonych badań i ich komercjalizacją.

W Polsce parki technologiczne traktuje się głównie jako instrument rozwoju gospodarki w ramach polityk: naukowej, innowacyjnej i technologicznej. Analizowane instytucje prorozwojowe mogą odgrywać stymulującą rolę w procesach restrukturyzacji regionalnych i lokalnych gospodarek. Zapewne w dłuższej perspektywie czasowej przyczyniać się będą do unowocześnienia polskiej gospodarki. Rozmieszczenie analizowanych instytucji prorozwojowych jest jednak znacznie przestrzennie zróżnicowane na obszarze Polski. Pewien niedosyt, $\mathrm{z}$ punktu widzenia istoty ich funkcjonowania, budzi zbyt niski udział instytucji $\mathrm{B}+\mathrm{R}$ w parkach technologicznych oraz wysoce niezadowalający stopień transferu i komercjalizacji technologii. Poważną barierą systemową dla rozwoju inicjatyw parków naukowo-technologicznych i innych instytucji inkubatorowych jest także niska intensywność współpracy uczelni z przemysłem oraz niewystarczający poziom usług finansowych wspierających nowoczesne przedsięwzięcia inwestycyjne. Wysoka intensywność pomocy publicznej często ma miejsce na obszarach największych aglomeracji miejskich, co może skutkować pojawianiem się efektu tzw. biegu jałowego.

Brak jest jednoznacznych zależności pomiędzy intensywnością pomocy publicznej a poziomem przedsiębiorczości czy rynkiem pracy. Pewien związek jest widoczny w wypadku poziomu rozwoju społeczno-gospodarczego. Przyczyną niskiego wpływu na aktywizację polskiej gospodarki analizowanych instytucji prorozwojowych jest jeszcze zbyt krótki okres ich funkcjonowania. 
Skuteczność parków technologicznych ma charakter wtórny w stosunku do istniejącej infrastruktury. Realny wpływ mają te parki, które posiadają szerokie zaplecze techniczne i naukowe w swoim otoczeniu. Na obszarach niskiego rozwoju społeczno-gospodarczego ich skuteczność może być ograniczona. Alternatywą jest tworzenie parków przemysłowych i inkubatorów przedsiębiorczości lub przekształcenie niektórych istniejących parków technologicznych w parki przemysłowe lub w inkubatory przedsiębiorczości.

\section{Literatura}

Bank Danych Regionalnych, www.stat.gov.pl/bdr_n/app/

Drozdowska J., 2009, „Przestrzenny wymiar pomocy publicznej w aktywizacji polskiej gospodarki”, Wrocław (maszynopis)

Furtak J., 2004, Parki naukowo-technologiczne jako instrument wspierania konkurencyjności i rozwoju regionu, Annales Universitatis Mariae Curie-Skłodowska Lublin Polonia, Sectio 8, nr 38, s. $121-132$

Guliński J., 2008, Stan ośrodków innowacji i przedsiębiorczości w Polsce, [w:] Materiały z XIX Konferencji SOOIPP, Krynica Zdrój

Kierunki udzielania pomocy publicznej $w$ latach 2007-2013, 2007, Ministerstwo Gospodarki, Warszawa

Mackiewicz M., 2008, Benchmarking parków technologicznych w Polsce. Wyniki badania, Polska Agencja Rozwoju Przedsiębiorczości, Warszawa

Marciniec B., 2007, Rola parków naukowo-technologicznych w rozwoju małych $i$ średnich przedsiębiorstw, Poznań

Matusiak K.B., 2007, Ośrodki innowacji i przedsiębiorczości w Polsce, SOOIPP Raport - 2007, Instytut Ekonomii Uniwersytetu Łódzkiego/Stowarzyszenie Organizatorów Ośrodków Innowacji i Przedsiębiorczości w Polsce, Łódź - Kielce - Poznań

Matusiak K., Bąkowski A. (red.), 2008, Wybrane aspekty funkcjonowania parków technologicznych w Polsce i na świecie, PARP, Warszawa

Matusiak K., Mażewska M., 2004, Wspieranie małej i średniej przedsiębiorczości w świetle ustawy o promocji zatrudnienia $i$ instytucjach na rynku pracy, Ministerstwo Gospodarki i Pracy, Warszawa

Parki technologiczne jako instrument polityki wspierania innowacji dyfuzji wiedz, 2008, Instytut Badań Strukturalnych. Warszawa

Pomoc publiczna w Regionalnym Programie Operacyjnym Województwa Opolskiego na lata 20072013, 2009, Opole

Raport końcowy z badań. Analiza stanu i kierunków rozwoju parków naukowo-technologicznych, inkubatorów technologicznych i centrów transferu technologii w Polsce, 2005, PARP, Warszawa

Raport o pomocy publicznej w Polsce udzielonej przedsiębiorcom 2000-2007, 2008, Urząd Ochrony Konkurencji i Konsumentów, Warszawa

Rozporzadzenie Rady Ministrów w sprawie sprawozdań o udzielonej pomocy publicznej oraz sprawozdań o zalegtych należnościach przedsiębiorców z tytulu świadczeń na rzecz sektora finansów publicznych z dn. 12 lipca 2007, Dz. U. 2007, nr 133, poz. 923

Specjalne strefy ekonomiczne (SSE) - zalażek Parków Przemysłowo-Technologicznych i klastrów, 2008, Informacje Sektorowe, PKO BP S.A., Warszawa

Ustawa o postępowaniu w sprawach dotyczqcych pomocy publicznej z dn. 30 kwietnia 2004 r., Dz. U. 2007, nr 59, poz. 404, z późn. zm.

Ustawa o zmianie ustawy o finansowym wspieraniu inwestycji oraz warunkach dopuszczalności i nadzorowaniu pomocy publicznej dla przedsiębiorców z dn. 29 sierpnia 2003 r., Dz. U. 2003, nr 159, poz. 1537 , z późn. zm. 
Wojnicka E., 2005, Możliwości wsparcia polskich instytucji proinnowacyjnych ze środków europejskich, [w:] Raport końcowy z badań. Analiza stanu i kierunków rozwoju parków naukowo-technologicznych, inkubatorów technologicznych i centrów transferu technologii w Polsce, PARP, Warszawa, s. 43-44

\section{Selected pro-developmental institutions related to public aid for the activation of Polish economy}

The paper focuses on selected pro-developmental institutions, related to the public aid granted by local government units, and their impact on the activation of Polish economy. It presents spatial diversity of localization of these institutions, as parks (industrial, technological, scientific and technological ones) and incubators (business and technological ones). The study identifies the conditions of localization and regularity of the spatial distribution of their operation. The authors make an attempt to identify and assess the impact of the analyzed institutions on the activation of Polish economy at the local and regional level, and their effectiveness in solving economic problems.

Keywords: pro-developmental institutions, technology park, business incubator, technology incubator, activation of economy.

Dr Paweł Brezdeń

Mgr Joanna Drozdowska

Dr Waldemar Spallek

Uniwersytet Wrocławski

Wydział Nauk o Ziemi i Kształtowania Środowiska

Instytut Geografii i Rozwoju Regionalnego

e-mail: brezden@geogr.uni.wroc.pl

e-mail:spallek@geogr.uni.wroc.pl 